\title{
Cannabis and the exocannabinoid and endocannabinoid systems. Their use and controversies
}

\section{Rebeca Olivia Millán-Guerrero ${ }^{1 *}$ and Sara Isais-Millán²}

${ }^{1}$ Universidad de Colima, Faculty of Medicine, Colima; ${ }^{2}$ Instituto de Seguridad y Servicios Sociales de los Trabajadores del Estado, Regional Hospital "Ignacio Zaragoza", Neurology Department, Mexico City. Mexico

\begin{abstract}
Cannabis (marijuana) is one of the most consumed psychoactive substances in the world. The term marijuana is of Mexican origin. The primary cannabinoids that have been studied to date include cannabidiol and delta-9-tetrahydrocannabinol, which is responsible for most cannabis physical and psychotropic effects. Recently, the endocannabinoid system was discovered, which is made up of receptors, ligands and enzymes that are widely expressed in the brain and its periphery, where they act to maintain balance in several homeostatic processes. Exogenous cannabinoids or naturally-occurring phytocannabinoids interact with the endocannabinoid system. Marijuana must be processed in a laboratory to extract tetrahydrocannabinol and leave cannabidiol, which is the product that can be marketed. Some studies suggest cannabidiol has great potentiaf for therapeutic use as an agent with antiepileptic, analgesic, anxiolytic, antipsychotic, anti-inflammatory and neuroprotective properties; however, the findings on cannabinoids efficacy and cannabis-based medications tolerability-safety for some condifions are inconsistent. More scientific evidence is required in order to generate recommendations on the use of medicinal cannábis.
\end{abstract}

KEY WORDS: Psychoactive substances. Cannabinoids. Endocannabinoid system.

\section{Introduction}

Cannabis (marijuana) is one of the most widely consumed psychoactive substances in the world. The term marijuana is of Mexican origin. For a long time, botanists believed that cannabis and hemp were two species. There are three uses of the plant:

- In temperate zones, hemp has a long history of use in the manufacture of clothing, industrial products, building materials, ropes, sails for boats, paint, varnish, solvent, fuel, paper, soap, shampoo, cosmetics; it is even consumed as food. ${ }^{1}$

- Use of the plant-drug for its therapeutic properties as an analgesic, sleep-inducer, antitussive, antiepileptic, etc.

- Recreational, hedonic and mystical use.

Cannabis leaves and flowers contain at least 489 compounds and 100 different phytocannabinoids. ${ }^{2}$
There are three main species of cannabis: Cannabis sativa, Cannabis indica and Cannabis ruderalis. ${ }^{3}$. The primary cannabinoids that have been studied to date include delta-9-tetrahydrocannabinol $(\Delta 9-\mathrm{THC}$, the most widely studied, responsible for most physical and psychotropic effects of cannabis), cannabialiol, cannabinol, cannabigerol and tetrahydrocannabivarin. ${ }^{4}$ The most abundant cannabinoids that the plant produces in different proportions are $\triangle 9$-THC and cannabidiol. ${ }^{5}$ Phytocannabinoids (cannabinoids of plant origin) have been used for millennia, and exogenous cannabinoid ligands tetrahydrocannabinol and cannabidiol were isolated from them. ${ }^{6}$

Recently, the endocannabinoid system was discovered, which consists of receptors, ligands and cenzymes that are widely expressed in the brain and periphery (Table 1), where they act to maintain balance in several homeostatic processes. ${ }^{7,8}$
Correspondence:

*Rebeca Olivia Millán-Guerrero

E-mail: millanrebeca@ hotmail.com
Date of reception: 03-12-2018

Date of acceptance: 02-05-2019

DOI: 10.24875/GMM.M20000334
Gac Med Mex. 2019;155:47ð5474

Contents available at PubMed

www.gacetamedicademexico.com license (http://creativecommons.org/licenses/by-nc-nd/4.0/). 
Table 1. Endocannabinoid system

\begin{tabular}{|c|c|c|c|c|c|}
\hline Cannabinoid & Receptor & Localization & Disease & Effect ${ }^{8}$ & $\stackrel{2}{=}$ \\
\hline ECS & CB1, TRPV1 & Brain and nerve terminals & Pain and migraine & $\begin{array}{l}\text { It inhibits the release of glutamate, reduc } \\
\text { intracellular calcium, promotes vasodilat } \\
\text { and preserved systolic function. It stimula } \\
\text { the production of capsain }\end{array}$ & 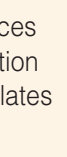 \\
\hline \multirow[t]{7}{*}{ Cannabidiol } & $\begin{array}{l}\text { CB1, CB2, } \\
\text { GPR55, FAAH }\end{array}$ & Brain and brainstem & Epilepsy & $\begin{array}{l}\text { 5-HT1A and glycine } \alpha 3 \text { and } \alpha 1 \text { receptor, } \\
\text { well as intracellular calcium receptor }\end{array}$ & as \\
\hline & $\mathrm{CBI}$ & Brain & $\begin{array}{l}\text { Severe traumatic brain } \\
\text { injury and stroke }\end{array}$ & Inhibits glutamate release & $\frac{\mathscr{c}}{\underline{\underline{n}}}$ \\
\hline & CB1 & Gastrointestinal tract & Digestive disorders & $\begin{array}{l}\text { Activates smooth muscle and digestive f } \\
\text { secretion }\end{array}$ & fluiar \\
\hline & CB1 & & Sleep disturbance & Neuromodulation & 4 \\
\hline & $\mathrm{CB} 1, \mathrm{CB} 2$ & Liver and pancreas & $\begin{array}{l}\text { Morbid obesity and } \\
\text { diabetes }\end{array}$ & Insulin resistance & $\frac{c}{\tilde{n}}$ \\
\hline & $\mathrm{CB} 1, \mathrm{CB} 2$ & & Cancer & $\begin{array}{l}\text { Delays cell proliferation process and } \\
\text { angiogenesis }\end{array}$ & 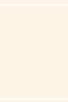 \\
\hline & $\begin{array}{l}\text { AEA decreases and } \\
2-A G \text { increases }\end{array}$ & Hypothalamic-pituitary axis & $\begin{array}{l}\text { Immediate response } \\
\text { to stress }\end{array}$ & Synaptic plasticity and memory & $\underset{ \pm}{\stackrel{c}{ \pm}}$ \\
\hline Cannabidiol & & $\begin{array}{l}\text { Decreases left amygdala } \\
\text { activity }\end{array}$ & Anxiety & & $\begin{array}{l}3 \\
\text { ò }\end{array}$ \\
\hline \multirow[t]{4}{*}{$\mathrm{THC}$} & & $\begin{array}{l}\text { Alteration in limbic and } \\
\text { cortical areas }\end{array}$ & Psychosis & & $\frac{\grave{c}}{\stackrel{c}{c}}$ \\
\hline & CB1, CB2 & Inhibits microglia & Alzheimer's disease & Neurotrophic factor-mediated neuroprote & ection \\
\hline & $\begin{array}{l}\text { CB1, CB2, AEA, } \\
2 A G\end{array}$ & Basal ganglia & Parkinson's disease & Modulates dopamine signaling & $\frac{c}{+\frac{c}{3}}$ \\
\hline & CB1, CB2, FAAH & Cortex/hippocampus & Huntington's disease & ECS receptor function decrease & 이 \\
\hline THC and CBD & CB1, CB2 & Spinal cord and brainstem & Multiple sclerosis & Spasticity and pain & 은 \\
\hline \multicolumn{5}{|c|}{$\begin{array}{l}\text { ECS }=\text { endocannabinoid system, } T H C=\text { delta-9-tetrahydrocannabinol, } C B 1=\mathrm{G} \text {-protein-coupled receptor }(\mathrm{GPCR}), \mathrm{CBD}=\text { cannabidiol, } \mathrm{CB} 2=\text { cannabinoid receptor type } 2, \\
2 \mathrm{AG}=2 \text {-arachidonoyl glycerol ligand, } \mathrm{TRPV} 1=\text { transient receptor potential vanilloid-1, } \mathrm{AEA}=\mathrm{N} \text {-arachidonoylethanolamine, } \mathrm{FAAH}=\text { fatty acid amide hydrolase. }\end{array}$} & 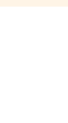 \\
\hline
\end{tabular}

\section{Receptors}

A G-protein-coupled receptor was isolated from murine neuroblastoma cells, called type 1 cannabinoid receptor (CB1), ${ }^{9}$ which is the most abundant G-protein-coupled receptor expressed in the mammalian brain, and has a neuromodulatory function; it is found at varying grades in all brain structures and in the periphery of almost all organs of the mammalian body. ${ }^{8}$ CB1 is expressed at the presynaptic (in glutamatergic and gamma-aminobutyric-ergetic neurons' terminals) and postsynaptic levels, associated with astrocytes, to regulate the release of neurotransmitters. ${ }^{10}$

Cannabinoid receptor type 2 (CB2) was isolated from human leukemia cells, and is is abundantly found in immune cells, in microglia and activated astrocytes.

The transient receptor potential vanilloid-1 (TRPV1) channel, known as capsaicin receptor (the active ingredient in chili peppers), is linked to a number of ligands other than capsaicin, including endocannâbinoid ligands, and can be activated by physical and mechanical stimuli such as low $\mathrm{pH}$, high temperatares or changes in osmotic concentration.

Finally, the G 55 protein-coupled GPR55 receptor, has an endogenous ligand, lysophosphatidylinositof; its role is not clear; it is expressed in cortical areas, in the striatum, the hippocampus and the cerebellum, and produces the opposite effect versus the $\mathrm{CB} 1$ receptor: it activates the release of neurotransmitters in presynaptic cells. It is also found in the periphery of the gastrointestinal tract, in osteoblasts and adipocytes ${ }^{6}$

\section{Ligands}

The endogenous cannabinoid or endocannabinoid receptor ligand, $\mathrm{N}$-arachidonoylethanolamine (AEA) or 
anandamide has been isolated from the pig's brain. ${ }^{11}$ The 2-arachidonoyl glycerol (2-AG) ligand has been isolated from canine intestinal tissue. ${ }^{9}$

When a presynaptic neuron releases a neurotransmitter to stimulate a postsynaptic neuron, the ligands spread passively and retrogradely to the presynaptic cell; they bind to the CB1 cannabinoid receptor and initiate a cascade that inhibits the release of neurotransmitters from the presynaptic cell and thus stops synaptic transmission. ${ }^{10-12}$ Therefore, AEA can be more active in acute processes and 2-AG in chronic processes.

\section{Biosynthetic and degrading enzymes}

Biosynthetic and degrading enzymes are the third main component of the endocannabinoid system; they modulate the synthesis and degradation of endogenous ligands, which influences on the system functionality: $\mathrm{N}$-arachidonoylethanolamine (AEA) or anandamide, diacylglycerol lipase (DAGL) $\alpha$ or $\beta$, fatty acid amide hydrolase (FAAH) of the serine hydrolase and monoacrylic glycerol lipase (MAGL) enzymes. There is still much to learn about these processes: FAAH and MAGL are promising for pharmacological manipulation of the signaling pathways of the endocannabinoid system.

\section{Relationship of phytocannabinoids and the endocannabinoid system}

Exogenous cannabinoids or natural-origin phytocannabinoids ${ }^{7,8}$ interact with the endocannabinoid system. The quintessential cannabinoid compound, $\triangle 9$-THC, binds to receptors $\mathrm{CB} 1$ and $\mathrm{CB} 2$ as a weak partial agonist; $\mathrm{CB} 1$ binding is believed to be primarily responsible for the intoxicating and psychotropic effects of the cannabis plant. Cannabidiol has low affinity for receptors $\mathrm{CB} 1$ or $\mathrm{CB} 2$, inhibits the binding of tetrahydrocannabinol to $\mathrm{CB} 1$, and can enhance or inhibit a variety of final effects on cells, from modulating intracellular calcium levels to the capacity to exert antioxidant properties; its activation has been shown to reduce the release of pro-inflammatory cytokines, which suggests its role in modulating inflammation and nociceptive responses to infection and injury. Unlike tetrahydrocannabinol, cannabidiol does not induce an intoxicating or psychotropic effect in the patient or user. ${ }^{13,14}$

TRPV1 receptor activation modulates a different pain stimulation pathway than those occupied by endocannabinoids. TRPV1 is also of potential use in the treatment of seizures and epilepsy; however, the precise mechanism whereby TRP channels influence on epilepsy remains unclear.

Cannabis is commonly consumed via inhalation or ingestion, and less frequently through ophthatmic, rectal, sublingual and dermal preparations. ${ }^{15}$ It is possible that persistent use of cannabis results in lasting neurocognitive deficits and that it affects brain structure and function. ${ }^{16}$ These neurophysiological atterations should be considered both in research and in clinical applications. ${ }^{17}$ There are studies that show a direct relationship between the risk of schizophrenia and the use of cannabis. ${ }^{18}$

Despite the above, there is no consensus in the scientific literature regarding the exact nature, maggnitude and duration of brain changes, which may depend on the frequency, quantity, duration and age at the beginning of cannabis use, as well as abstinence duration. In addition, it is also not clear whether the identified alterations are a consequence of or precede consumption. Additional longitudinal studies evautuating larger samples, particularly prior to the stapt of cannabis use, are needed in order to determine a causal route between cannabis use and these alterations. Something similar happened with tobacco: it was necessary for 30 or more years of consumption to be elapsed to know the consequences on health. 19

The use of medicinal cannabis has legal, ethical and social implications. In the United States, marifuana is currently recognized by the Drug Enforcement Agency (DEA) as a type I controlled substance. The Food and Drugs Administration (FDA) does not approve marijuana as a safe or effective drug for any indication. The European Medicines Agency (EMA) gives tetrahydrocannabinol and cannabidiol the designation of "orphan drugs", with the consequent therapeutic utility and safety in rare diseases. ${ }^{20}$

Marijuana must be processed in a laboratory to extract tetrahydrocannabinol, which is responsible for the intoxicating and psychotropic effects of cannabis, and leave cannabidiol, the product that can be warketed. Cannabis products can become contaminated by improper preparation and storage and develop-any microorganism, particularly bacteria and fungi (motos). There are reports of bacterial contamination with Salmonella and Enterobacter, Streptococcus Fand Klebsiella, as well as cases of fungal spores, inclưding Aspergillus strains. ${ }^{21}$

Some studies attribute cannabidiol great potential for therapeutic use as an antiepileptic, analgesic, 
anxiolytic, antipsychotic, anti-inflammatory and neuroprotective drug. ${ }^{22}$ There are inconsistent findings on the efficacy of cannabinoids in neuropathic pain and painful spasms in multiple sclerosis, as well as regarding the tolerability and safety of cannabis-based medications for any chronic pain. ${ }^{23}$ There is also limited evidence of their association with the risk of shortterm adverse effects and potential mental adverse effects, such as psychosis. ${ }^{24}$

There are not enough well-designed randomized trials to confirm the benefits and harms of cannabis use. Cannabinoids adverse effects are unclear because there is scarce methodological evidence to quantify them. Much of what is known about medicinal cannabis adverse effects comes from studies related to marijuana recreational use. Therefore, long-term investigations around the assessment of adverse effects associated with medicinal cannabis chronic use are necessary, in order to conclusively assess the risks with an extended period of use. ${ }^{25}$

In view of the considerable limitations of available studies, and in accordance with the conclusions of several meta-analyses, it is not possible to recommend cannabis or cannabis-based medicine as a treatment for musculoskeletal pain, arthritis or fibromyalgia. There is an imperious need for well-controlled clinical trials of a larger scope. ${ }^{22,26}$

\section{Conclusion}

Cannabis medicinal use needs more evidence obtained with scientific criteria, since there have not been well-designed clinical studies with substantial samples and sufficient duration, which are factors that are essential for research quality and reliability.

\section{References}

1. Kuddus M, Ginawi IAM, Al-Hazimi A. Cannabis sativa: an ancient wild edible plant of India. Emir J Food Agric. 2013;25:736-745.
2. Elsohly MA, Slade D. Chemical constituents of marijuana: The complex mixture of natural cannabinoids. Life Sci. 2005;78:539-548.

3. Schultes RE, Klein WM, Plowman T, Lockwood TE. Cannabis: an example of taxonomic neglect. Bot Mus Lealf Harv Univ.1974;23:337-367.

4. Williamson EM, Evans FJ. Cannabinoids in clinical practice. Drugs. 2000;60:1303-1314.

5. Small E. Evolution and classification of cannabis sativa (marijuana, hemp) in relation to human utilization. Bot Rev. 2015;81:189-294.

6. Lannotti FA, Di Marzo V, Petrosino S. Endocannabinoids and endocannabinoid-related mediators: targets, metabolism and role in neurological disorders. Prog Lipid Res. 2016;62:107-128.

7. Russo E, Guy GW. A tale of two cannabinoids: the therapeutic rationale for combining tetrahydrocannabinol and cannabidiol. Med Hypotheses. 2006;66:234-246.

8. Russo EB. Cannabidiol claims and misconceptions. Trends Pharmacol Sci. 2017;38:198-201

9. Matsuda LA, Lolait SJ, Brownstein MJ, Young AC, Bonner TI. Struteture of a cannabinoid receptor and functional expression of the cloned CDNA. Nature. 1990;346:561-564.

10. Di Marzo V, Piscitelli $F$. The endocannabinoid system and its modutation by phytocannabinoids. Neurotherapeutics. 2015;12:692-698.

11. Devane WA, Hanus L, Breuer A, Pertwee RG, Stevenson LA, Griffin G, et al. Isolation and structure of a brain constituent that binds to the cannabinoid receptor. Science. 1992;258:1946-1949.

12. Morena M, Patel S, Bains JS, Hill MN. Neurobiological interactioñ between stress and the endocannabinoid system. Neuropsychopharmacology. 2016;41:80-102.

13. Russo EB, Burnett A, Hall B, Parker KK. Agonistic properties of cannabidiol at 5-HT1a receptors. Neurochem Res. 2005;30:1037-1043. 으

14. Benito C, Tolon RM, Pazos MR, Núñez E, Castillo Al, Romero JCCannabinoid $\mathrm{CB} 2$ receptors in human brain inflammation. Br J Pharmacol. 2008; 153:277-285.

15. Dryburgh LM, Bolan NS, Grof ChPL, Galettis P, Schneider J, ̌̀ al Cannabis contaminants: sources, distribution, human toxicity and pharmacologic effects. Br J Clin Pharmacol. 2018;84:2468-2476.

16. Iversen L. Cannabis and the brain. Brain. 2003:126:1252-1270

17. Filbey FM, Aslan S, Lu H, Peng SL. Residual effects of THC vią̂ovel measures of brain perfusion and metabolism in a large group of chronic cannabis users. Neuropsychopharmacology. 2018:43:700-707. C

18. Pasman JA, Verweij KJH, Gerring Z, Stringer S, Sanchez-Roige S, Treur JL, et al. GWAS of lifetime cannabis use reveals new risk Ioci, genetic overlap with psychiatric traits, and a causal influence of schizophrenia. Nat Neurosci. 2018;21:1161-1170.

19. Nader DA, Sánchez ZM. Effects of regular cannabis use on neurō̄ognition, brain structure, and function: a systematic review of findings in adults. Am J Drug Alcohol Abuse. 2018:44:4-18.

20. Codas M, Haurón G, Achucarro D, Usher F, Pescador-Ruschel MA, Sebriano M, et al. Cannabis en el dolor crónico. Rev Virtual Soc Parag Med Int. 2018;5,12-18.

21. Dryburgh LM, Bolan NS, Grof CPL, Galettis P, Schneider J, LucaS CJ, et al. Cannabis contaminants: sources, distribution, human toxicity and pharmacologic effects. Br J Clin Pharmacol. 2018;84:2468-2476.

22. Bridgeman MB, Abazia DT. Medicinal cannabis: history, pharmacology, and implications for the acute care setting. PT. 2017:42:180-188.0

23. Häuser W, Petzke F, Fitzcharles MA. Efficacy, tolerability and safety of cannabis-based medicines for chronic pain management-an overview of systematic reviews. Eur J Pain. 2018;22:455-470.

24. Nugent SM, Morasco BJ, O'Neil ME, Freeman M, Low A, Kondo Ket al. The effects of cannabis among adults with chronic pain and an overview of general harms: a systematic review. Ann Intern Med. 2017;167:319-331.

25. Karila L, Roux P, Rolland B, Benyamina A, Reynaud M, Aubin HJ et al. Acute and long-term effects of cannabis use: a review. Curr Pharmpes. 2014;20:4112-4118

26. Perrot S, Trouvin AP. Cannabis for musculoskeletal pain and arthritis: evidence is needed. Joint Bone Spine. 2018:86:1-3. 